\title{
Budaya Organisasi dalam Lembaga Islam
}

\author{
Asep Iwan Setiawan \\ UIN Sunan Gunung Djati Bandung \\ E-mail: iwanfidkom@uinsgd.ac.id
}

\begin{abstract}
Every organization has a culture that aims to make every member can have a handle in the pursuit of goals. Organizational climate will become less favorable, the relationship between the employee will only be limited to normal relations without guided by the spirit of togetherness that is bound by the same values. Therefore every individual of a very important part of the organization upholding cultural values developed from year to year, which is rooted in strong values that will give birth to the employees believed a strong commitment. If this is ignored it will produce less karayawan commitment, motivation and performance levels of employees who are not satisfactory, which in turn will damage the company itself.
\end{abstract}

\section{Kata Kunci:}

Budaya Organisasi, Kinerja, Lembaga Islam

\section{A. Pendahuluan}

Manusia sebagai makhluk sosial dalam kehidupannya senantiasa berinteraksi dengan manusia lainnya, hal itulah yang membuat manusia suka berkelompok yang kemudian disebut sebagai organisasi. Perilaku manusia dalam organisasi dengan berbagai dinamika permasalahan yang dihadapi individu anggota organisasi maupun organisasi secara keseluruhan yang semakin kompleks. Hal ini menunjukkan bahwa penangangan terhadap manusia perlu dilakukan secara berkelanjutan (suistanaible), karena manusia merupakan unsur utama dalam organisasi yang harus dikelola secara efektif.

Organisasi merupakan wadah bagi masyarakat dengan tujuan dapat meraih hasil yang sebelumnya tidak tercapai jika dilakukan oleh individu secara sendiri-sendiri. Perilaku organisasi merupakan suatu studi yang menyangkut aspek-aspek perilaku manusia pada kelompok tertentu atau juga dapat dikatakan sebagai ilmu yang mempelajari 
tentang perilaku, struktur dan proses dalam organisasi sangat erat dengan hubungan antar manusia dalam organisasi dan organisasi diciptakan oleh manusia untuk mencapai tujuan (dalam Rivai dan Mulyadi, 2010: 171).

Dalam berorganisasi tidak terlepas dari kehidupan bermasyarakat, yang senantiasa terikat oleh budaya yang diciptakan. Ikatan budaya tercipta oleh masyarakat yang bersangkutan, baik dalam keluarga, organisasi, bisnis, suku maupun bangsa. Budaya membedakan masyarakat satu dengan yang lain dalam cara berinteraksi dan bertindak menyelesaikan suatu pekerjaan. Budaya mengikat anggota kelompok masyarakat menjadi satu kesatuan pandangan yang menciptakan keseragaman berperilaku atau bertindak. Budaya sebagai sesuatu yang dimiliki organisasi seiring dengan bergulirnya waktu, dapat pula dirasakan manfaatnya dalam memberi kontribusi bagi efektivitas organisasi secara keseluruhan, dan efisiensi dari manajemen dalam organisasi tersebut.

Budaya dalam organisasi harus memiliki nilai-nilai yang telah diyakini, dijunjung tinggi, dan menjadi motor penggerak oleh kebanyakan anggota organisasi sebagai aturan main yang sah untuk mencapai tujuan yang dikehendaki, membuat nilai-nilai itu menjadi budaya organisasi. Budaya organisasi merupakan sistem penyebaran kepercayaan dan nilai-nilai yang berkembang dalam suatu organisasi dan mengarahkan perilaku anggota-anggotanya. Budaya organisasi dapat menjadi instrumen keunggulan kompetitif yang utama, yaitu bila budaya organisasi mendukung strategi organisasi, dan bila budaya organisasi dapat menjawab atau mengatasi tantangan lingkungan dengan cepat dan tepat.

Berdasarkan penelitian Chatab kegagalan budaya organisasi disebabkan oleh konflik budaya organisasi. Hasil penelitian ini menyatakan bahwa 74 persen perusahaan atau organisasi mengalami ketidakberhasilan karena tidak memperhatikan faktor budaya (Nevizond, 2007: 1).

Brown menyatakan bahwa budaya organisasi mengacu kepada sistem makna bersama yang dianut oleh anggota-anggota suatu organisasi, dan membedakan organisasi itu dari organisasi-organisasi yang lain. Tata nilai dalam budaya organisasi dapat berperan sebagai 
sumber kekuatan penting yang diyakini dan dianut secara luas dalam menghadapi tantangan perubahan lingkungan. Namun budaya organisasi dapat menjadi beban bagi keberhasilan apabila budaya organisasi tidak sesuai dengan tujuan organisasi. Misalnya siatuasi lingkungan industri yang menuntut adanya adaptasi dan perubahan organisasi, namun di sisi lain budaya organisasi menginginkan tidak adanya perubahan dan mempertahankan status quo, maka organisasi akan mengalami inertia (kelemahan) yang pada akhirnya dapat mengalami kemunduran (Brown, 1998: 306).

Keberadaan suatu perusahaan komersial (industri) pada umumnya mempunyai tujuan jangka panjang yang dilandasi dengan motif ekonomi untuk menghasilkan nilai-nilai tambah dan manfaat ekonomi bagi stakeholders yang meliputi para pemegang saham, karyawan, mitra kerja dan masyarakat umumnya. Untuk memujudkan nilai-nilai tambah dan manfaat ekonomi tersebut, perusahaan diharapkan mempunyai visi, misi, strategi program kerja yang terencana dan terfokus dan berkesinambungan.

Untuk menghasilkan karyawan yang profesional dengan integritas yang tinggi, diperlukan acuan baku yang diberlakukan diperusahaan yang dapat dijadikan pedoman dalam organisasi tersebut yang secara sistematis menuntun para karyawan untuk meningkatkan komitmen kerjanya bagi perusahaan. Acuan tersebut merupakan seperangkat peraturan yang dapat membentuk sikap dan perilaku sesuai dengan visi dan misi serta strategi perusahaan.

Budaya dapat dipahami dari sebuah artefak menjadi sebuah strategi. Hari ini, berarti strategi untuk selamat dan menang dalam persaingan global. Tentunya budaya dalam sebuah organisasi harus dihadirkan dalam perilaku anggota dari organisasi.

\section{B. Pengertian Budaya Organisasi}

Budaya telah menjadi konsep penting dalam memahami masyarakat dan kelompok manusia untuk waktu yang lama. Stoner dan kawan-kawan memberikan arti budaya sebagai gabungan kompleks asumsi, tingkah laku, cerita, mitos, metafora dan berbagai ide lain yang menjadi satu untuk menentukan apa arti menjadi anggota tertentu (Moeljono, 2005: 8). 
Dalam beberapa literatur pemakaian istilah corporate culture biasa diganti dengan istilah organization culture. Secara antropologis, Ashley Montagu mengatakan bahwa budaya adalah pola berpikir dan bertindak yang tercermin dalam aktivitas kehidupan manusia (Poespowardojo, 1989: 219). Pola-pola seperti akhirnya membentuk way of life, yaitu cara hidup tertentu dari suatu masyarakat, yang sekaligus mencerminkan identitas masyarakat tersebut. Atau seperti yang dikatakan Christopher Dawson culture is a common way of life kultur sebagai cara hidup bersama (Poespowardojo, 1989: 219). Meski pengertian ini mulanya hanya digunakan untuk membedakan way of life dari satu masyarakat dengan masyarakat yang lain, akhirnya pengertian ini diadopsi untuk membedakan satu organisasi dengan organisasi lain dengan asumsi bahwa dalam pengertian yang lebih sempit, organisasi identik dengan masyarakat. Dalam konteks organisasi, pengertian budaya misalnya diberikan oleh Stanley Davis (1984: 4) menyatakan,

"Budaya organisasi adalah pola keyakinan dan nilai-nilai organisasi yang dipahami, dijiwai dan dipraktekkan (shared) oleh anggota organisasi sehingga pola tersebut memberikan makna tersendiri bagi organisasi bersangkutan dan menjadi dasar aturan berperilaku didalam organisasi"

Pengertian ini memberi arti bahwa organisasi yang berbeda akan mempunyai sistem makna yang berbeda pula. Perbedaan sistem makna dari satu organisasi menyebabkan organisasi tersebut mempunyai karakteristik yang unik, berbeda dengan karakteristik organisasi lainnya yang pada gilirannya menjadikan sebuah organisasi mempunyai respon yang berbeda dengan organisasi lain ketika kedua organisasi tersebut menghadapi masalah yang sama (Gagliardi, t.th.: 119). Demikian juga perbedaan sistem makna tersebut menyebabkan perbedaan perilaku para anggota organisasi dan perilaku organisasi itu sendiri.

Moeljono Djokosantoso (2003: 17-18) menyatakan bahwa budaya korporat atau budaya manajemen atau juga dikenal dengan istilah budaya kerja merupakan nilai-nilai dominan yang disebarluaskan didalam organisasi dan diacu sebagai filosofi kerja karyawan. Susanto (1997: 3) memberikan definisi budaya organisasi sebagai nilai-nilai yang menjadi pedoman sumber daya manusia untuk menghadapi permasalahan eksternal dan usaha penyesuaian integrasi ke dalam 
perusahaan sehingga masing-masing anggota organisasi harus memahami nilai-nilai yang ada dan bagaimana mereka harus bertindak atau berperilaku.

Robbins mendefinisikan budaya organisasi (organizational culture) sebagai suatu sistem makna bersama yang dianut oleh anggotaanggota yang membedakan organisasi tersebut dengan organisasi yang lain (Robbins, 2008: 248). Lebih lanjut, Robbins menyatakan bahwa sebuah sistem pemaknaan bersama dibentuk oleh warganya yang sekaligus menjadi pembeda dengan organisasi lain. Sistem pemaknaan bersama merupakan seperangkat karakter kunci dari nilai-nilai organisasi ("a system of shared meaning held by members that distinguishes the organization from other organization. This system of shared meaning is, on closer examination, a set of key characteristics that the organization values"). Robbins memberikan karakteristik budaya organisasi sebagai berikut:

1. Inovasi dan keberanian mengambil risiko (Inovation and risk taking), adalah sejauh mana organisasi mendorong para karyawan bersikap inovatif dan berani mengambil resiko. Selain itu bagaimana organisasi menghargai tindakan pengambilan risiko oleh karyawan dan membangkitkan ide karyawan;

2. Perhatian terhadap detil (Attention to detail), adalah sejauh mana organisasi mengharapkan karyawan memperlihatkan kecermatan, analisis dan perhatian kepada rincian.

3. Berorientasi kepada hasil (Outcome orientation), adalah sejauh mana manajemen memusatkan perhatian pada hasil dibandingkan perhatian pada teknik dan proses yang digunakan untuk meraih hasil tersebut.

4. Berorientasi kepada manusia (People orientation), adalah sejauh mana keputusan manajemen memperhitungkan efek hasil-hasil pada orang-orang di dalam organisasi.

5. Berorientasi tim (Team orientation), adalah sejauh mana kegiatan kerja diorganisasikan sekitar tim-tim tidak hanya pada individu-individu untuk mendukung kerjasama.

6. Agresifitas (Aggressiveness), adalah sejauh mana orang-orang dalam organisasi itu agresif dan kompetitif untuk menjalankan budaya organisasi sebaik-baiknya. 
7. Kemantapan (Stability), adalah sejauh mana kegiatan organisasi menekankan status quo sebagai kontras dari pertumbuhan.

Selain itu, Robbins (2008: 294) mengungkapkan bahwa budaya organisasi berfungsi:

1. Budaya menciptakan pembedaan yang jelas antara satu organisasi dan yang lain.

2. Budaya membawa suatu rasa identitas bagi anggota-anggota organisasi.

3. Budaya mempermudah timbulnya komitmen pada sesuatu yang lebih luas daripada kepentingan diri individual seseorang.

4. Budaya merupakan perekat sosial yang membantu mempersatukan organisasi itu dengan memberikan standarstandar yang tepat untuk dilakukan oleh karyawan.

5. Budaya sebagai mekanisme pembuat makna dan kendali yang memandu dan membentuk sikap serta perilaku karyawan.

Dapat disimpulkan bahwa budaya organisasi sebagai pegangan seluruh jajaran perusahaan untuk beroperasi, dengan memiliki fungsi:

a. Membedakan antara organisasi yang satu dengan lainnya.

b. Menciptakan identitas

c. Membangkitkan rasa kebersamaan,

d. Meningkatkan stabilitas sosial

e. Pedoman dan alat kontrol yang membimbing dan membentuk sikap dan perilaku karyawan.

Dengan kata lain bahwa fungsi budaya dalam organisasi, dapat dijelaskan sebagai berikut :

1. Budaya mempunyai peran menetapkan tapal batas, artinya budaya menciptakan pembedaan yang jelas antara satu organisasi dengan yang lain.

2. Budaya membawa suatu rasa identitas bagi anggota-anggota organisasi.

3. Budaya mempermudah timbulnya komitmen pada suatu yang lebih luas daripada kepentingan diri individual seseorang.

4. Budaya itu meningkatkan kemantapan sistem sosial. Budaya merupakan perekat sosial yang membantu mempersatukan organisasi itu dengan memberikan standar-standar yang tepat dalam bertindak. Budaya berfungsi sebagai mekanisme 
pembuat makna dan kendali yang memandu dan membentuk sikap serta perilaku para karyawan.

\section{Menciptakan dan Mempertahankan Budaya}

Budaya organisasi tidak muncul begitu saja, namun bila sudah muncul maka budaya tersebut sukar untuk dipadamkan, artinya akan melekat dalam perilaku organisasi tersebut. Kebiasaan, tradisi dan caracara umum yang dilakukan sebelumnya dan tingkat keberhasilan yang diperoleh dengan usaha keras tersebut, ini membimbing ke sumber paling akhir dari budaya suatu organisasi. Karena disadari bahwa budaya organisasi menyangkut nilai-nilai yang dipahami dan dianut bersama dalam suatu organisasi. Nilai tersebut dapat terbentuk melalui beberapa cara antara lain: pimpinan, pendiri/ pemilik dan interaksi antar individu dalam organisasi.

Setelah proses perekrutan dan seleksi karyawan perlu diadakan penyamaan perspepsi mengenai budaya dari organisasi tersebut. Oleh karena itu organisasi akan membantu karyawan baru menyesuaikan diri dengan budaya yang telah ditetapkan pada perusahaan tersebut. Hal ini dilakukan sebagai upaya pengenalan dan sosialisasi dengan proses adaptasi karyawan dengan budaya organisasi.

Adapun tahapannya sebagai berikut:

1. Tahap prakedatangan; periode ini dilakukan pembelajaran pada proses sosialisasi yang dilakukan sebelum karyawan baru bergabung dalam organisasi,

2. Tahap keterlibatan, yakni proses sosialisasi di mana karyawan baru melihat apa yang sesungguhnya organisasi itu dan persimpangan yang mungkin dan kenyataan yang ada.

3. Tahap metamorfosis adalah proses sosialisasi di mana karyawan baru berubah dan menyesuaikan diri dengan pekerjaan, kelompok kerja dan organisasi (Robbins, 2008: 723733).

Dalam tahapan diatas perlu media sosialisasi dari perusahaan agar penanaman budaya organisasi dapat berjalan dengan baik. Media yang digunakan diantaranya:

1. Cerita, biasanya berisi dongeng peristiwa mengenai pendiri organisasi, pelanggaran aturan, sukses dari miskin ke kaya, 
pengurangan angkatan kerja, lokasi karyawan, reaksi terhadap kesalahan masa lalu dan dan cara mengatasi masalah. Hal ini dapat memberikan penjelasan atas praktik-praktik yang dilakukan pada saat ini, juga menautkan masa kini ke masa lampau.

2. Ritual, yakni deretan kegiatan berulang yang mengungkapkan dan memperkuat nilai-niali utama organisasi, sasaran apakah yang paling penting, orang-orang manakah yang penting dan mana yang dapat dikorbankan

3. Lambang kebendaan, menyampaikan pesan kepada karyawan siapa yang penting, sejauh mana egalitarianisme yang diinginkan oleh eksekutif puncak, jenis perilaku (misalnya pengambilan resiko, konservatif, otoriter, partisipatif, individualistis, sosial) yang tepat.

4. Bahasa, sebagai sarana untuk mengidentifikasi anggota budaya dan sub budaya. Dengan mempelajari bahasa, anggota organisasi membuktikan penerimaan mereka akan budaya itu dan dengan berbuat seperti itu membantu melestarikannya (Robbins, 2008: 723-733).

Menurut Sonnenfeld (dalam Robbins, 2008: 723-733) ada empat tipe budaya organisasi:

a. Akademi, perusahaan suka merekrut para lulusan muda universitas, memberi mereka pelatihan istimewa, dan kemudian mengoperasikan mereka dalam suatu fungsi yang khusus. Perusahaan lebih menyukai karyawan yang lebih cermat, teliti, dan mendetail dalam menghadapi dan memecahkan suatu masalah.

b. Kelab, perusahaan lebih condong ke arah orientasi orang dan orientasi tim dimana perusahaan memberi nilai tinggi pada karyawan yang dapat menyesuaikan diri dalam sistem organisasi. Perusahaan juga menyukai karyawan yang setia dan mempunyai komitmen yang tinggi serta mengutamakan kerja sama tim.

c. Tim Bisbol, perusahaan berorientasi bagi para pengambil resiko dan inovator, perusahaan juga berorientasi pada hasil yang dicapai oleh karyawan, perusahaan juga lebih menyukai karyawan yang agresif. Perusahaan cenderung untuk mencari 
orang-orang berbakat dari segala usia dan pengalaman, perusahaan juga menawarkan insentif finansial yang sangat besar dan kebebasan besar bagi mereka yang sangat berprestasi.

d. Benteng, perusahaan condong untuk mempertahankan budaya yang sudah baik. Menurut Sonnenfield banyak perusahaan tidak dapat dengan rapi dikategorikan dalam salah satu dari empat kategori karena mereka memiliki suatu paduan budaya atau karena perusahaan berada dalam masa peralihan

\section{Kinerja Karyawan dan Budaya Organisasi}

Seseorang akan selalu mendambakan penghargaan terhadap hasil pekerjaanya dan mengharapkan imbalan yang adil. Penilaiaan kinerja perlu dilakukan seobyektif mungkin karena akan memotivasi karyawan dalam melakukan kegiatannya. Disamping itu penilaan kinerja dapat memberikan informasi untuk kepentingan pemberian gaji, promosi dan melihat perilaku karyawan.

Menurut Waldman kinerja merupakan gabungan perilaku dengan prestasi dari apa yang diharapkan dan pilihannya atau bagian syaratsyarat tugas yang ada pada masing-masing individu dalam organisasi. Sedangkan menurut Mangkunegara; kinerja dapat didefinisikan sebagai hasil kerja secara kualitas dan kuantitas yang dapat dicapai oleh seseorang karyawan dalam melaksanakan tugas sesuai dengan tanggung jawab yang diberikan kepadanya. Cascio dalam Koesmono mengatakan bahwa kinerja merupakan prestasi karyawan dari tugastugasnya yang telah ditetapkan. Soeprihantono; mengatakan bahwa kinerja merupakan hasil pekerjaan seorang karyawan selama periode tertentu dibandingkan dengan berbagai kemungkinan, misalnya standard, target/sasaran/criteria yang telah ditentukan terlebih dahulu dan telah disepakati bersama

Keutamaan budaya organisasi merupakan pengendali dan arah dalam membentuk sikap dan perilaku manusia yang melibatkan diri dalam suatu kegiatan organisasi. Molenaar, Kotter dan Heskett; Budaya mempunyai kekuatan yang penuh, berpengaruh pada individu dan kinerjanya bahkan terhadap lingkungan kerja. Buchanan dan Huczyski, dalam Koesmono; elemen-elemen budaya organisasi atau perusahaan 
adalah nilai-nilai, kepercayaan-kepercayaan, pendapat-pendapat, sikapsikap dan norma-norma. Budaya pada dasarnya merupakan totalitas pola tingkah laku sosial, seni, keyakinan, kelembagaan, dan produk kerja, serta pemikiran manusia lainnya dari suatu komunitas atau populasi tertentu, atau merupakan nilai yang disumbangkan oleh orang dalam suatu kelompok yang cenderung bertahan dalam waktu yang relatif lama, meskipun anggota kelompoknya mengalami perubahan.

Nilai-nilai moral dari karyawan harus tetap dibina, tentunya hal ini akan berkorelasi positif dengan kinerja dari karyawan tersebut. Adapun kegiatan manajemen yang dapat mendukung dalam penanaman hal-hal etis dalam budaya organisasi diungkapkan oleh Sthephen P. Robbins (2008: 740), yakni:

a. Jadilah model yang kelihatan, dalam Islam hal ini disebutkan sebutkan ada uswah hasanah dari para pemimpin yang menjadi model untuk tolok ukur perilaku yang tepat.

b. Komunikasikanlah harapan etis,

c. Berikanlah pelatihan etis

d. Berikanlah imbalan secara terang-terangan terhadap tindakan etis dan berikan hukuman terhadap tindakan yang tidak etis,

e. Sediakanlah mekanisme yang bersifat melindungi,

\section{E. Budaya Organisasi dan Spiritualitas}

Pendekatan untuk membangun budaya organisai dengan spiritualitas pada saat ini banyak dilakukan oleh perusahaan dengan metode pelatihan diantaranya ESQ (Emosional Spiritual Quetiont) dari Ary Ginanjar, UTHB (Umat Terbaik Hidup Berkah) dari Samsul Arifin, PMQ (Pelatihan Manajemen Qalbu) dari Aa Gym, dan masih banyak lagi pelatihan yang mengintegrasikan budaya organisasi di perusahaan dengan kekuatan spiritualitas agar karyawan dapat bekerja dengan profesional dengan memiliki moral yang baik.

Dalam perilaku spiritualitas ditempat kerja hal ini merupakan bentuk pengakuan bahwa orang memiliki kehidupan batiniah yang memelihara dan dipelihara oleh pekerjaan bermakna yagn ada dalam konteks masyarakat. Konz dan Ryan dalam artikelnya pada Journal of Organizational Change Management yang berjudul maintaining an organizational spirituality: no easy task, bahwa budaya organisasi 
berasal dari substansi spiritual dalam pendiri dan pemimpin organisasi yang disampaikan melalui visi-misi organisasi, kebijakan, dan prosedur. "Kunci untuk menjaga budaya organisasi adalah filosofi dan nilai-nilai organisasi pemimpinnya.

Demikian pula dengan Intel, Wal Mart, Xerox, Ford, Nike, dan Harley Davidson yang juga mendukung spiritualitas dalam lingkungan kerja. Para pakar organisasi telah menemukan hubungan yang positif antara spiritualisasi dalam lingkungan kerja dengan tingkat kemajuan perusahaan. Spiritualitas kerja mempengaruhi peningkatan kesehatan fisik dan mental karyawan, kemajuan pribadi dan meningkatkan rasa harga diri; Organisasi dengan spiritualitas kerja memiliki tingkat pertumbuhan lebih cepat, tingkat keuntungan yang lebih tinggi, dan meningkatkan efisiensi lebih dari organisasi komparatif yang tidak membangun spiritualitas kerja.

Menurut penelitian, integrasi spiritual dengan tempat kerja terjadi dalam tiga tahap:

1. Tahap jiwa yang gelap, yaitu keadaan di mana simbol-simbol dunia yang begitu mencekam, sekarang tidak lagi mempunyai banyak arti. Contoh, mobil mewah adalah simbol status yang amat dibanggakan oleh sebagian besar orang. Namun ketika orang mencapai pencerahan, ia menyadari, kebanggaan tadi hanyalah permainan ego yang tidak mau kalah. Ego yang selalu ingin bersaing. Di kedalaman hati, ada ruh yang selalu kehausan untuk memperoleh manfaat dari harta benda tadi. Menurut ruh, harta tadi mestilah bisa bermanfaat untuk menambah amal sebagai bekal di alam kelanggengan.

2. Pencarian spiritual, ini merupakan pencarian prinsip-prinsip spiritual yang ia dambakan. Contoh, ketika orang mengalami kehancuran dalam bisnis, dan kemudian mencari keteduhan pada tataran spiritual, orang itu akan begitu bernafsu mencari lebih banyak lagi ajaran yang mampu memuaskan dahaga spiritualnya.

3. Integrasi spiritual. Ini adalah keadaan di mana orang belajar menerapkan prinsip-prinsip ajaran spiritual ke dalam setiap aspek kehidupan, termasuk di tempat kerjanya. Contoh, jika tadinya seseorang menganggap anak hanya sebagai akibat logis dari pergaulan suami istri, sekarang ia melihat, di balik jasmani 
anak-anak itu ada suatu daya yang sedang mewujudkan ekspresinya. Anak yang bermain, anak yang menyanyi, nakal, bandel, namun juga amat lucu, merupakan ekspreasi dari energi yang sedang berekspresi (dalam Suryanto, Spirituality Transformational Leadership: Terobosan Baru Menjadi Pemimpin Unggul, www.pemimpinunggul.com)

Orang yang telah bertransformasi spiritual akan mencari nilainilai luhur dari pekerjaannya. Jika tadinya bekerja hanya dianggap sebagai pencari nafkah, ia mengganggap, ia juga berperan ikut berbuat kebaikan bagi dunia ini, melalui produk-produk yang dijual oleh perusahaan tempat ia bekerja. Ia anggap bekerja sebagai sarana menuju kepada Tuhannya.

Pertanyaannya, apakah orang harus melalui peristiwa besar seperti bercerai, kematian suami/istri, kecelakaan dan sebagainya untuk bisa mengalami transformasi spiritual? Tidak selalu. Di sekeliling kita, kita akan menjumpai ada orang yang begitu saleh, begitu taat beragama.

Ketika ia bekerja, orang itu bekerja dengan jujur, penuh kasih sayang, dan begitu takut kepada Tuhannya sehingga ia tidak korupsi, manipulasi, dan melakukan hal-hal yang merugikan orang lain atau perusahaannya. Tingkah laku yang terpuji itu merupakan hasil dari praktek yang ia lakukan yang berdasar pada ajaran agamanya.

Namun sering pula kita menjumpai orang yang begitu taat beribadah, dan kelihatan saleh, namun begitu bicara, bicaranya menyakitkan hati. Ritual yang ia jalani secara ketat ternyata tak mampu mengekangnya untuk korupsi, manipulasi, dan menyakiti hati orang lain. Orang ini bisa kita katakan belum tertransformasi secara spiritual. Namun bisa saja ia berubah secara total hanya karena ia membaca buku tertentu. Ketika membaca buku itu, hatinya yang beku bagaikan gunung es, perlahan mencair menjadi aliran bening yang membawa serpihan kesombongan pada dirinya. Ia kemudian berubah menjadi bijaksana, peduli, dan penuh kasih. Saat itulah ia mengalami transformasi spiritual.

Organisasi-organisasi yang mempromosikan budaya spiritual mengakui bahwa orang yang memiliki pikiran dan roh, berusaha menemukan makna dan tujuan hidup dalam kerja mereka dan ingin 
berhubungan dengan uman manusia lain dan ingin menjadi bagian dari masyarakat.

Adapun karakterisitik budaya organisasi yang tampak dalam organisasi spiritualitas, seperti diungkapkan oleh Robbins (2008: 746):

1. Sangat memperhatikan tujuan, dengan membangun budaya berdasar tujuan yang bermanfaat,

2. Fokus pada pengembangan individu, hal ini diwujudkan dengan mengakui bobot dan nilai orang, tidak hanya memberikan jabatan tetapi juga berusaha menciptakan budaya yang memungkinkan karyawan dapat terus menerus belajar dan bertumbuh.

3. Kepercayaan dan keterbukaan, hal ini diwujudkan dengan para manajer tidak takut mengakui kesalahan.

4. Pemberdayaan karyawan,

5. Toleransi terhadap ekspresi karyawan.

\section{F. Penutup}

Budaya organisasi sebagai corporate culture sebagai upaya perwujudan untuk menjadi good governance. Budaya organisasi sengaja dirumuskan dan diturunkan dari visi serta misi perusahaan. Diharapkan dengan terciptanya budaya organisasi, hubungan komuniksi menjadi lebih kondusif dan yang paling penting terciptanya etos kinerja perusahaan atau organisasi yang mendorong tujuan lebih baik.

Organisasi tanpa budaya hanya akan menjadi sekumpulan orangorang yang tidak memiliki pegangan dalam mengejar tujuan. Iklim organisasi akan menjadi kurang kondusif, hubungan antar karyawan hanya akan sebatas hubungan biasa tanpa dilandasi oleh semangat kebersamaan yang diikat oleh nilai-nilai yang sama. Oleh karena itu setiap individu dari bagian organisasi sangat penting menjunjung tinggi nilai-nilai budaya yang dikembangkan dari tahun ke tahun yang berakar pada nilai yang kuat diyakini karyawan sehingga akan melahirkan komitmen yang kuat. Jika hal ini diabaikan maka akan menghasilkan karayawan yang kurang komitmen, motivasi serta tingkat kinerja dari karyawan yang tidak memuaskan yang pada akhirnya akan merusak perusahaan itu sendiri. 
Dalam hal ini nilai-nilai spiritualitas, perlu ditanamkan kepada karyawan. Al-Qur'an menghendaki kebaikan. Dengan kata lain, manusia beriman tidak boleh berpaling dari perilaku baik, sekalipun dalam kondisi lingkungannya cenderung mengerahkan manusia tersebut kepada keburukan dan ketidaksenangan. Hal itulah yang menginspirasi dakwah untuk senantiasa melakukan amar ma'ruf nahyi munkar. Kelemahan fisik, kehabisan tenaga atau kesukaran tidak akan pernah menghalangi mereka untuk bersikap konsisten dalam kebaikan. Itulah karyawan yang itqan (doing the best at possible quality) serta yang tak kalah penting manajer dalam perusahaan memanusiakan manusia, bukan menganggap manusia sebagai mesin sehingga "hilang rasa kemanusiaannya".[]

\section{DAFTAR PUSTAKA}

Brown, Andrew. 1998. Organizational Culture. Harlow. Pearson Education Limited.

Chatab, Nevizond. 2007. Profil Budaya Organisasi Mendiagnosis Budaya dan Merangsang Perubahannya. Bandung. PT. Alfabeta Bandung.

Davis, S. 1984. Managing Corporate Culture, Cambridge, MA: Belinger

Gagliardi, P. (1986), The creation and Change of Organizational Culture: A Conceptional Framework, Organization Studies, Vol. 7, no. 2, pp.119-134

Hampden-Turner, Charles and Trompenaars, Alfons. 1993. The Seven Cultures of Capitalism ; Value System for Creating Wealth in the United Stated, Japan, Germany, France, Britain, Sweden, and the Netherlands. Doubleday. London.

Moeljono, Djokosantoso, 2003. Budaya Korporat dan Keunggulan Korporasi, Elex Media Komputindo, Jakarta.

Moeljono, Djokosantoso, 2005 Cultured! Budaya Organisasi dalam Tantangan, Elex Media Komputindo, Jakarta.

Poespowardojo, S. 1989. Strategi Kebudayaan: Suatu Pendekatan Filosofis, Jakarta: Gramedia.

Rivai, Veitzhzal dan Mulyadi, Deddy. 2010. Kepemimpinan dan Perilaku Organisasi Jakarta: Raja Grafindo 
Robbins, Stephen P., 1998. Organization Behavior, Concepts, Controversies, Application. Seventh Edition, Englewood Cliffs dan PT. Prenhallindo, Jakarta.

Sobirin, Achmad. 2007. Budaya Organisasi Pengertian, Makna dan Aplikasinya dalam Kehidupan Organisasi. Yogyakarta. Unit Penerbit dan Percetakan Sekolah Tinggi Ilmu Manajemen YKPN.

Susanto, AB., 1997. Budaya Perusahaan : Seri Manajemen Dan Persaingan Bisnis. Cetakan Pertama, Elex Media Komputindo, Jakarta.

Toha, Miftah. 2001, Perilaku Organisasi, Konsep Dasar dan Aplikasinya, Jakarta: RajaGrafindo Persada. 